\title{
Palliative care in Primary Health Care: an integrative literature review
}

\author{
Cuidados paliativos na Atenção Primária à Saúde: revisão integrativa de literatura \\ Cuidados paliativos en la Atención Primaria de Salud: una revisión integradora de la literatura
}

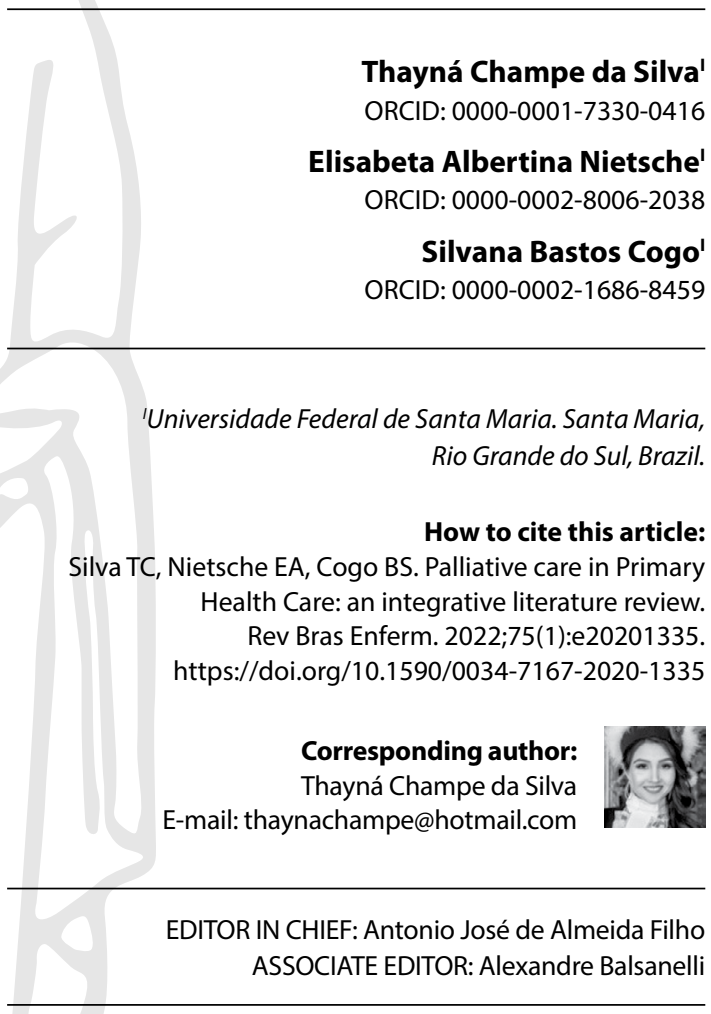

Submission: $01-23-2021$
Approval: 05-28-2021

\begin{abstract}
Objectives: to analyze scientific evidence on the implementation and performance of palliative care in Primary Health Care. Methods: an integrative literature review, according to the Preferred Reporting Items for Systematic Reviews and Meta-Analyses, carried out in the PubMed, SciVerse Scopus and LILACS databases, in December 2020, without a time frame. Results: 22 original scientific articles were analyzed, 14 classified as evidence level VI. The objective was to understand the experiences and roles of professionals, patients and families on palliative care in Primary Health Care, articles focused on the theme of management and organization of health services and on the importance of educational interventions on the subject. Final Considerations: evidence found relating palliative care in Primary Health Care points to the possibility of this care; health teams work closely with the family and their home, but the need to expand this theme is still perceived.
\end{abstract}

Descriptors: Primary Health Care; Palliative Care; Nursing; Family Health Strategy; Review.

\section{RESUMO}

Objetivos: analisar evidências cientificas sobre a implementação e realização dos cuidados paliativos na Atenção Primária à Saúde. Métodos: revisão integrativa da literatura, segundo o Preferred Reporting Items for Systematic Reviews and Meta-Analyses, realizada nas bases de dados PubMed, SciVerse Scopus e LILACS, em dezembro de 2020, sem recorte temporal. Resultados: foram analisados 22 artigos científicos originais, 14 classificados com nível de evidência VI. Objetivou-se compreender as experiências e os papéis de profissionais, pacientes e familiares sobre cuidados paliativos na Atenção Primária à Saúde, artigos voltados para a temática de gestão e organização dos serviços de saúde e sobre a importância de intervenções educativas na temática. Considerações Finais: evidências encontradas relacionando cuidados paliativos na Atenção Primária à Saúde apontam para a possibilidade desse cuidado; equipes de saúde atuam de maneira próxima a família e seu domicílio, porém ainda se percebe a necessidade de ampliação deste tema.

Descritores: Atenção Primária à Saúde; Cuidados Paliativos; Enfermagem; Estratégia Saúde da Família; Revisão.

\section{RESUMEN}

Objetivos: analizar la evidencia científica sobre la implementación y desempeño de los cuidados paliativos en la Atención Primaria de Salud. Métodos: revisión integradora de la literatura, de acuerdo con el Preferred Reporting Items for Systematic Reviews and MetaAnalyses, realizada en las bases de datos PubMed, SciVerse Scopus y LILACS, en diciembre de 2020, sin marco temporal. Resultados: se analizaron 22 artículos científicos originales, 14 clasificados como nivel de evidencia VI. El objetivo fue conocer las vivencias y roles de los profesionales, pacientes y familiares sobre los cuidados paliativos en Atención Primaria de Salud, artículos centrados en el tema de la gestión y organización de los servicios de salud y en la importancia de las intervenciones educativas sobre el tema. Consideraciones Finales: la evidencia encontrada que relaciona los cuidados paliativos en Atención Primaria de Salud apunta a la posibilidad de este cuidado; Los equipos de salud trabajan en estrecha colaboración con la familia y su hogar, pero aún se percibe la necesidad de ampliar este tema. Descriptores: Atención Primaria de Salud; Cuidados Paliativos; Enfermería; Estrategia de Salud Familiar; Revisión. 


\section{INTRODUCTION}

The most recent definition of palliative care (PC) was published in 2018 and developed after a broad project involving more than 400 members from 88 countries of the International Association for Hospice \& Palliative Care (IAHPC), an association that maintains close ties and official relations with the World Health Organization $(\mathrm{WHO})^{(1)}$. Currently, PC is defined as "active holistic care, offered to people of all ages who are in intense suffering related to their health, resulting from a serious illness, especially those at the end of life. The objective of PC is, therefore, to improve the quality of life of patients, their families and their caregivers"(1).

$\mathrm{PC}$ is part of the scope of action of Primary Health Care (PHC). In this regard, $P C$ clearly contemplate the assessment of symptoms promoted by a multidisciplinary team, which aims to improve patients' quality of life (adults and children) and their families, facing a disease or injury that threatens the continuity of life through the prevention and relief of suffering, early identification, impeccable assessment and treatment of pain and other physical, social, psychological and spiritual symptoms ${ }^{(1)}$.

Advances in health, science and technology have contributed to the increasing life expectancy of populations, which has provided challenges to health systems, which began to offer assistance to a greater number of individuals with different health conditions. This situation also prompted the change of focus of PC, who were originally directed to cancer and specialized care. Currently, its concept has been extended to other Chronic Non-Communicable Diseases (CNCDs) and other care settings ${ }^{(2)}$.

One of these environments is $\mathrm{PHC}$, considering the agreement made in the Tripartite Inter-Management Commission (CIT), on October 31, 2018, which provides for the guidelines for the organization of PC, in light of integrated continuous care, under the Unified System of Health (SUS - Sistema Único de Saúde). PC must be part of a continuous integrated care offered within the Health Care Network and will be eligible for any person affected by a life-threatening disease, whether acute or chronic, based on the diagnosis of this condition. PHC, organizer of the network and coordinator of care, is responsible for monitoring users with lifethreatening diseases in its territory, prevailing the longitudinal care offered by primary care teams, together with the Expanded Family Health Center (NASF-AB - Núcleo Ampliado de Saúde da Familia), with the rear of the other care network points ${ }^{(3)}$.

In Brazil, since the 70s, isolated discussions and initiatives have been found in PC. It is noteworthy, however, that it was in the 1990s that the first organized services began to emerge. It is noteworthy that, in the 1980s, the life expectancy of Brazilians was 62.5 years. Currently, the reality is different, the numbers have increased, life expectancy has risen to 76 years, in addition to the number of services that provide PC in the country. This increase in life expectancy is the result of investments in public policies by the State and even the implementation and implementation of SUS ${ }^{(1)}$.

Until August 2018, after a survey carried out by the Brazilian National Academy of Palliative Care (ANPC - Academia Nacional de Cuidados Paliativos), 177 PC services distributed in the five regions of Brazil were identified. Of these, $58 \%$ (103 services) are concentrated in southeastern, 20\% (36 services), in northeastern, 14\%
(25 services), in southern, 5\% (eight services), in center-western, while only $3 \%$ (five services) are located in northern Brazil ${ }^{(3)}$.

In the Brazilian scenario, PHC is implemented through Family Health Strategy (FHS), which was proposed in the country in 2006 after the publication of the Ministerial (MO)/Ministry of Health (MoH) Ordinance in the 648 of March 28, 2006. However, Ordinance MO/ MoH 963, of May 27, 2013, also describes the role of PHC in home care in PC, designated as Home Care type 1 (AD1), with the objective of serving the population with the following characteristics: patients with controlled/compensated health problems and with physical difficulty or impossibility to travel to a health unit and those who need less complex, less frequent care, with less need for health resources. This document also establishes the organization of specialized assistance through the Home Care Services (HCS) and the work of Multidisciplinary Home Care Teams (MHCT) $)^{(4)}$.

Therefore, $\mathrm{PHC}$ starts to play a leading role in coordinating the PC. Holistic assessment and PC should be started early, not just in the final moments of life. It is believed that PHC plays an important role in these care scenarios, in addition to collaborating in the transition between secondary/tertiary and home care ${ }^{(4)}$. Therefore, when analyzing the current context of population aging and the increase in CNCDs and the importance of PHC in Brazil, it is relevant to carry out studies aimed at the debate around this theme.

In order to cooperate for the planning, elaboration and execution of public policies, as well as for assistance with $\mathrm{PC}$, this research seeks to synthesize publications on $\mathrm{PC}$ at $\mathrm{PHC}$, highlighting the challenges for the implementation of this care at this level of care, in order to propose reflection and changes in health professionals' and managers' work.

\section{OBJECTIVES}

To analyze scientific evidence on the implementation and performance of palliative care in Primary Health Care.

\section{METHODS}

This is a qualitative study, using the integrative literature review method, according to the flowchart of preferred reporting items for systematic reviews and meta-analyses (PRISMA) ${ }^{(5)}$, including experimental or almost experimental primary quantitative studies, in order to answer the following guiding question: what scientific evidence is available on the implementation of $\mathrm{PC}$ in $\mathrm{PHC}$ ?

In order to comply with the methodological rigor to meet the requirements of the integrative review, six steps were taken: establishment of the hypothesis and objectives of the integrative review, establishment of inclusion and exclusion criteria for articles (selection of the sample), definition of the information to be extracted from the selected articles, analysis of results, discussion and presentation of results ${ }^{(6)}$. It is noteworthy that the critical analysis of selected publications was considered and treated descriptively, qualitatively and the results presented followed the PRISMA rigor and recommendations.

The search was conducted in June 2018, updated in December 2020, in the PubMed databases, SciVerse Scopus and Latin American and Caribbean Literature on Health Sciences. The descriptors Palliative Care, Primary Health Care, Family Health 
Strategy were selected from indexed terms in structured vocabulary DeCS (Descriptors in Health Sciences) and in PubMed's article indexing vocabulary, the Medical Subject Headings (MeSH terms). The search strategies used for the selection of articles were: Palliative Care AND Primary Health Care; LILACS and Scopus: Palliative Care AND Primary Health Care, Palliative Care AND Family Health Strategy. Primary articles in Portuguese, English and Spanish, which included the theme PC at PHC, fully available, without time frame, were included. It should be noted that the different search strategies and the non-use of time delimitation have provided opportunities for the expansion of the possibility of locating evidence that answered the search question. To detail the information collected from the articles, we used a form containing title, journal, year of publication, objective, methodology level of evidence and challenges.

For data treatment, Bardin's content analysis was used, firstly, a text skimming of all the transcribed material was carried out, followed by a pre-analysis. Subsequently, clipping, aggregation and enumeration of data were carried out, allowing for clarification of the indications of categories. Then, the categorization itself was started, whose information contained in the studies formed the corpus of analysis, which led to the elaboration of indicators that were submitted to analytical procedures and subsequent inference, comparing with literature data ${ }^{(7)}$.

Categorization was the form adopted to analyze the results, in which it was extracted how PC is being performed/implemented at PHC. The work of analyzing the studies consisted of a careful task. The analysis' objective was to know and characterize the general overview of all studies according to their investigated object.

Studies identified through the bibliographic search in databases

1. Descriptors: Palliative Care AND Primary Health Care; PubMed: 2,699 publications 2. Descriptors: Palliative Care AND Primary Health Care; Scopus: 0 publication; LILACS: 15 publications 3. Descriptors: Palliative Care AND Family Health Strategy; Scopus: 03 publications; LILACS: 01 publication

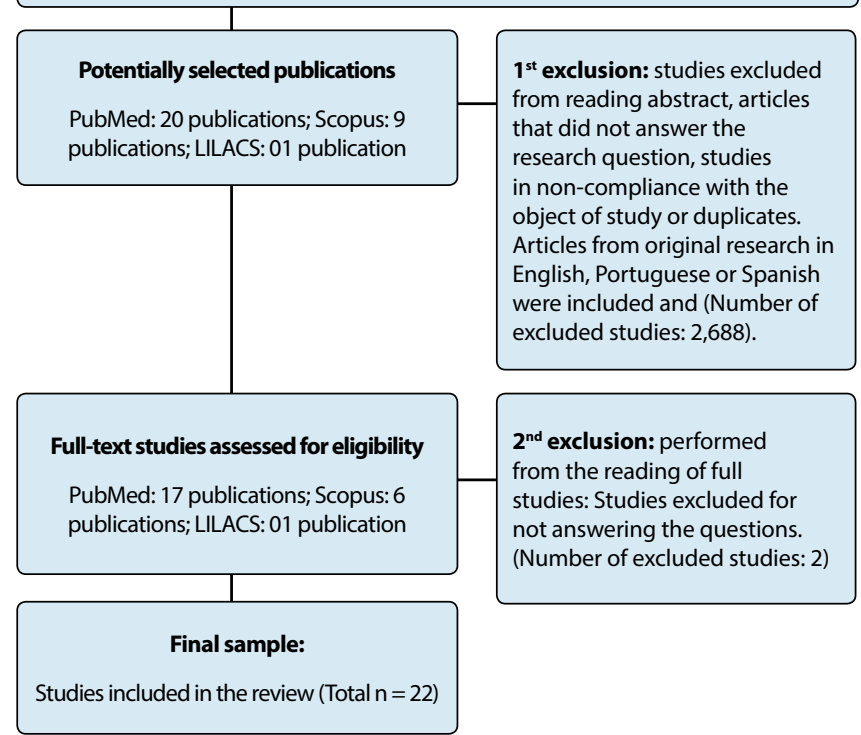

Figure 1 - Flowchart representative of the inclusion process of articles included in the review according to PRISMA, Santa Maria, Rio Grande do Sul, Brazil, 2020

\section{RESULTS}

Regarding the characterization of all articles analyzed, two (9\%) were published in 2020, six (27\%) in 2016, four (18\%) in 2015, two (9\%), in 2017, two (9\%), in 2013, four (18\%) in 2012 and two (9\%) in 2010. Among the studies, nine (40\%) were published in journals aimed specifically at PC, three (13\%) in family health journals, two (9\%) in a public health journal (4\%), three (15\%) in nursing journals, two (9\%) in a geriatric medicine journal and two (9\%) journals in related fields.

With regard to study design, the highest percentage is the qualitative approach, eight (36\%), followed by four (20\%) descriptive (qualitative), three (15\%) cross-sectional studies, three (15\%) case study, one (5\%) randomized clinical trial, one (5\%) randomized comparative, two (9\%) analytical.

In the present study, to facilitate the visualization of results found, a chart was built containing the articles' titles, the journals in which they were published, the year of publication, objective, method and level of evidence (Chart 1):

A validated instrument was used to define the level of evidence for each study, namely: I- systematic reviews or meta-analysis; IIrandomized, controlled study, evidence derived from at least one well-designed randomized controlled clinical trial; III- controlled clinical trial without randomization, evidence from well-designed clinical trials, without randomization; IV- case-control or cohort, evidence from well-designed cohort and case-control studies; V-systematic review of qualitative or descriptive studies; VI- qualitative or descriptive study; VII- expert opinion or consensus ${ }^{(30)}$.

It is observed that 10 (48\%) articles have the following objectives: to understand the experiences and roles of professionals, patients and families regarding $\mathrm{PC}$ at $\mathrm{PHC}$, followed by eight articles (36\%) focused on the theme of management and organization of health services, which addressed different aspects, such as diagnostic criteria and eligibility for PC, situational diagnosis of PC and proposals and tools aimed at the organization of PC at $\mathrm{PHC}$ and on the importance of educational interventions on the subject, with four (18\%) scientific productions.

To facilitate the visualization of results found, a synoptic chart (Chart 2) was constructed with information on the article number and the challenges presented for the context of $\mathrm{PHC}$ regarding the realization and implementation of $P C$.

The general context of the studies was variable, as different experiences of PHC nurses, family members and caregivers and their relationship with $P C$ were found $\left.{ }^{(8,12,18-19}\right)$; the relationship between patients at home level and $\mathrm{PHC}$ professionals responsible for their care ${ }^{(9,13,17)}$; the $\mathrm{PC}$ work process at $\mathrm{PHC}$, its potentials and difficulties ${ }^{(3,11,14-16,20-29)}$ as well as educational and training on the topic in question ${ }^{(10,13)}$.

\section{DISCUSSION}

The importance of multidisciplinary teams appears as fundamental in five ${ }^{(18,21-22,26-27)}$ articles, with an emphasis on the need for theoretical, scientific and technical knowledge and specific clinical skills in the domain of different professions so that integrality of actions can occur in the PC offer process, thus contemplating physical, psychosocial and spiritual dimensions of patients and their families. 
Chart 1 - Characterization of articles analyzed in the integrative review about palliative care in Primary Health Care, Santa Maria, Rio Grande do Sul, Brazil, 2020, $(n=20)$

\begin{tabular}{|c|c|c|c|c|c|}
\hline ARTICLE & TITLE & $\begin{array}{l}\text { JOURNAL/YEAR } \\
\text { OF PUBLICATION }\end{array}$ & OBJECTIVE & METHOD & $\begin{array}{l}\text { LEVEL OF } \\
\text { EVIDENCE }\end{array}$ \\
\hline $\mathrm{A} 1^{(8)}$ & $\begin{array}{l}\text { Palliative care in the home: perceptions } \\
\text { of nurses in the Family Health Strategy }\end{array}$ & $\begin{array}{l}\text { Acta Paul Enferm. } \\
2012\end{array}$ & $\begin{array}{l}\text { Understand the perception of FHS nurses in } \\
\text { relation to PCs at home. }\end{array}$ & $\begin{array}{l}\text { Descriptive, } \\
\text { exploratory, } \\
\text { qualitative study }\end{array}$ & $\mathrm{Vl}$ \\
\hline $\mathrm{A} 2^{(9)}$ & $\begin{array}{l}\text { Case management n primary palliative } \\
\text { care is associated more strongly with } \\
\text { organizational than characteristics: } \\
\text { results from a cross-sectional } \\
\text { prospective study }\end{array}$ & $\begin{array}{l}\text { BMC Palliat Care. } \\
2015\end{array}$ & $\begin{array}{l}\text { Describe and investigate characteristics of } \\
\text { patients and the organizational environment, } \\
\text { related to the number of contacts and times } \\
\text { that cases are discussed between patients and } \\
\text { professional case managers. }\end{array}$ & $\begin{array}{l}\text { Cross-sectional } \\
\text { study }\end{array}$ & $\mathrm{Vl}$ \\
\hline $\mathrm{A} 3^{(10)}$ & $\begin{array}{l}\text { Developing an innovative model of } \\
\text { palliative care in the community in } \\
\text { Brazil }\end{array}$ & $\begin{array}{l}\text { BMJ Support } \\
\text { Palliat Care. } 2015\end{array}$ & $\begin{array}{l}\text { Propose a PC model in the public health } \\
\text { service in Brazil, offered through Primary Care } \\
\text { to the community. }\end{array}$ & Descriptive & $\mathrm{Vl}$ \\
\hline $\mathrm{A} 4^{(11)}$ & $\begin{array}{l}\text { Interaction of palliative care and } \\
\text { primary care }\end{array}$ & $\begin{array}{l}\text { Clin Geriatr Med. } \\
2015\end{array}$ & $\begin{array}{l}\text { Analyze the primary PC skill set and criteria } \\
\text { to consider when patients are eligible for } \\
\text { specialized PC. }\end{array}$ & Experience report & $\mathrm{Vl}$ \\
\hline $\mathrm{A} 5^{(12)}$ & $\begin{array}{l}\text { The role of UK district nurses in } \\
\text { providing care for adult patients } \\
\text { with a terminal diagnosis: a meta- } \\
\text { ethnography }\end{array}$ & $\begin{array}{l}\text { Int J Palliat Nurs. } \\
2015\end{array}$ & $\begin{array}{l}\text { Explore the role of UK district nurses in } \\
\text { providing care to adult patients with a terminal } \\
\text { diagnosis. }\end{array}$ & Meta-ethnographic & V \\
\hline$A 6^{(13)}$ & $\begin{array}{l}\text { Palliative care case managers in } \\
\text { primary care: a descriptive study of } \\
\text { referrals in relation to aims }\end{array}$ & $\begin{array}{l}\text { J Palliat Med. } \\
2015\end{array}$ & $\begin{array}{l}\text { Investigate referral of patients to primary care } \\
\text { case managers in relation to three elements. }\end{array}$ & $\begin{array}{l}\text { Cross-sectional } \\
\text { study }\end{array}$ & $\mathrm{Vl}$ \\
\hline$A 7^{(14)}$ & $\begin{array}{l}\text { Promoting palliative care in the } \\
\text { community: production of the primary } \\
\text { palliative care toolkit by the European } \\
\text { Association of Palliative Care Taskforce } \\
\text { in primary palliative care }\end{array}$ & $\begin{array}{l}\text { Palliat. Med. } \\
2015\end{array}$ & $\begin{array}{l}\text { Document barriers and facilitators to PC in } \\
\text { the community and produce grants for PC } \\
\text { specialists. }\end{array}$ & $\begin{array}{l}\text { Cross-sectional } \\
\text { study }\end{array}$ & V \\
\hline$A 8^{(15)}$ & $\begin{array}{l}\text { Anticipatory prescribing in terminal } \\
\text { care at home: what challenges do } \\
\text { the community health professionals } \\
\text { encounter? }\end{array}$ & $\begin{array}{l}\text { BMJ Support } \\
\text { Palliat Care. } 2013\end{array}$ & $\begin{array}{l}\text { Explore the challenges faced by primary } \\
\text { and community health professionals in } \\
\text { Leicestershire and Rutland related to the } \\
\text { advance prescription of care for terminally ill } \\
\text { patients who wish to remain at home to die. }\end{array}$ & Qualitative study & $\mathrm{Vl}$ \\
\hline$A 9^{(16)}$ & $\begin{array}{l}\text { Palliative care in Primary Care: } \\
\text { presentation of a case }\end{array}$ & $\begin{array}{l}\text { Semergen. } \\
2013\end{array}$ & $\begin{array}{l}\text { Present the case study of a patient diagnosed } \\
\text { with glioblastoma multiforme. }\end{array}$ & Case study & $\mathrm{Vl}$ \\
\hline $\mathrm{A} 10^{(17)}$ & $\begin{array}{l}\text { Clinical effectiveness of online training } \\
\text { in palliative care of primary care } \\
\text { physicians }\end{array}$ & $\begin{array}{l}\text { J Palliat Med. } \\
2013\end{array}$ & $\begin{array}{l}\text { Test the clinical effectiveness of online } \\
\text { education in PC for physicians through impacts } \\
\text { on symptom control and quality of life. }\end{array}$ & $\begin{array}{l}\text { Randomized } \\
\text { clinical trial }\end{array}$ & II \\
\hline $\mathrm{A} 11^{(18)}$ & $\begin{array}{l}\text { Integrating palliative care information } \\
\text { and hospice referral in medicaid } \\
\text { primary care }\end{array}$ & $\begin{array}{l}\text { J Palliat Med. } \\
2013\end{array}$ & $\begin{array}{l}\text { Assess an intervention to improve } \\
\text { communication about early care planning and } \\
\text { facilitate PC referral. }\end{array}$ & Analytical & $\mathrm{Vl}$ \\
\hline $\mathrm{A} 12^{(19)}$ & $\begin{array}{l}\text { Do rural primary health care nurses } \\
\text { feelequipped for palliative care? }\end{array}$ & $\begin{array}{l}\text { Aust J Prim Health. } \\
2012\end{array}$ & $\begin{array}{l}\text { Explore nurses' experiences and determine } \\
\text { how they feel personally and professionals } \\
\text { equipped to provide palliative services. }\end{array}$ & Qualitative & $\mathrm{Vl}$ \\
\hline $\mathrm{A} 13^{(20)}$ & $\begin{array}{l}\text { How family physicians address } \\
\text { diagnosis and management of } \\
\text { depression in palliative care patients }\end{array}$ & $\begin{array}{l}\text { Ann Fam Med. } \\
2012\end{array}$ & $\begin{array}{l}\text { Explore family doctors' opinions on } \\
\text { knowledge, diagnosis and treatment of } \\
\text { depression in PC. }\end{array}$ & $\begin{array}{l}\text { Comparative } \\
\text { analysis }\end{array}$ & $\mathrm{Vl}$ \\
\hline $\mathrm{A} 14^{(21)}$ & $\begin{array}{l}\text { Primary palliative care: the potential of } \\
\text { primary care physicians as providers of } \\
\text { palliative care in the community in the } \\
\text { Eastern Mediterranean region }\end{array}$ & $\begin{array}{l}\text { East Mediterr } \\
\text { Health J. } \\
2012\end{array}$ & $\begin{array}{l}\text { Assess the urgent need for providing } \mathrm{PC} \text { in the } \\
\text { region. }\end{array}$ & Descriptive & V \\
\hline $\mathrm{A} 15^{(22)}$ & $\begin{array}{l}\text { Participatory knowledge exchange to } \\
\text { support palliative care in Chile: lessons } \\
\text { learned through global health research }\end{array}$ & $\begin{array}{l}\text { Can J Nurs Res. } \\
2011\end{array}$ & $\begin{array}{l}\text { Support the provision of } \mathrm{PC} \text { in vulnerable } \\
\text { contexts through a participatory process of } \\
\text { knowledge exchange, through qualitative and } \\
\text { participatory methodologies. }\end{array}$ & Qualitative & $\mathrm{Vl}$ \\
\hline $\mathrm{A} 16^{(23)}$ & $\begin{array}{l}\text { Effects of online palliative care } \\
\text { training on knowledge, attitude and } \\
\text { satisfaction of primary care physicians }\end{array}$ & $\begin{array}{l}\text { BMC Fam Pract. } \\
2011\end{array}$ & $\begin{array}{l}\text { Compare the knowledge and attitude of } \\
\text { primary care physicians in relation to PC for } \\
\text { patients with advanced cancer as well as job } \\
\text { satisfaction. }\end{array}$ & $\begin{array}{l}\text { Educational } \\
\text { randomized } \\
\text { controlled trial for } \\
\text { comparison }\end{array}$ & ॥ \\
\hline $\mathrm{A} 17^{(24)}$ & $\begin{array}{l}\text { Palliative and support care at home in } \\
\text { primary care }\end{array}$ & $\begin{array}{l}\text { Gac Sanit. } \\
2011\end{array}$ & $\begin{array}{l}\text { Estimate the proportion of people who need } \\
\text { PC and support at home in primary care and } \\
\text { describe their characteristics. }\end{array}$ & Descriptive study & $\mathrm{Vl}$ \\
\hline
\end{tabular}


Chart 1 (concluded)

\begin{tabular}{|c|c|c|c|c|c|}
\hline ARTICLE & TITLE & $\begin{array}{l}\text { JOURNAL/YEAR } \\
\text { OF PUBLICATION }\end{array}$ & OBJECTIVE & METHOD & $\begin{array}{l}\text { LEVEL OF } \\
\text { EVIDENCE }\end{array}$ \\
\hline $\mathrm{A} 18^{(25)}$ & $\begin{array}{l}\text { Palliative care for a child: role of a } \\
\text { primary care doctor }\end{array}$ & $\begin{array}{l}\text { Malays Fam } \\
\text { Physician. } \\
2011\end{array}$ & $\begin{array}{l}\text { Highlight the important role of primary care } \\
\text { physicians in providing care. }\end{array}$ & Case study & VI \\
\hline $\mathrm{A} 19^{(26)}$ & $\begin{array}{l}\text { Shared care in basiclevel palliative } \\
\text { home care: organizational and } \\
\text { interpersonal challenges }\end{array}$ & $\begin{array}{l}\text { J Palliat Med. } \\
2010\end{array}$ & $\begin{array}{l}\text { Analyze the views of health professionals on } \\
\text { interprofessional cooperation at the basic level } \\
\text { of home PC for patients with terminal cancer. }\end{array}$ & $\begin{array}{l}\text { Descriptive } \\
\text { qualitative study }\end{array}$ & VI \\
\hline$A 20^{(27)}$ & $\begin{array}{l}\text { Developing targets for public health } \\
\text { initiatives to improve palliative care }\end{array}$ & $\begin{array}{l}\text { BMC PublicHealth. } \\
2010\end{array}$ & $\begin{array}{l}\text { Develop the first targets of public health } \\
\text { initiatives to improve PC in Germany. }\end{array}$ & Qualitative study & $\mathrm{VI}$ \\
\hline $\mathrm{A} 21^{(28)}$ & $\begin{array}{l}\text { Os sentidos da atenção domiciliar } \\
\text { no cuidado ao idoso na finitude: a } \\
\text { perspectiva humana do profissional } \\
\text { do SUS }\end{array}$ & $\begin{array}{l}\text { Ciênc. saúde } \\
\text { coletiva. } \\
2020\end{array}$ & $\begin{array}{l}\text { Understand the meanings of home care in } \\
\text { the scope of primary care actions in elderly } \\
\text { care from the perspective of SUS health } \\
\text { professionals. }\end{array}$ & $\begin{array}{l}\text { Qualitative } \\
\text { theoretical- } \\
\text { methodological } \\
\text { approach }\end{array}$ & VI \\
\hline $\mathrm{A} 22^{(29)}$ & $\begin{array}{l}\text { Cuidados paliativos providos por } \\
\text { médicos de família e comunidade na } \\
\text { atenção primária à saúde brasileira }\end{array}$ & $\begin{array}{l}\text { Revista Brasileira } \\
\text { De Medicina } \\
\text { De FamíliaE } \\
\text { Comunidade, } \\
2020 .\end{array}$ & $\begin{array}{l}\text { Characterize the practice of PC provided by } \\
\text { family and community physicians in Brazilian } \\
\text { primary care. }\end{array}$ & $\begin{array}{l}\text { Cross-sectional and } \\
\text { descriptive study }\end{array}$ & V \\
\hline
\end{tabular}

$P C$ - palliative care.

Chart 2 - Characterization of challenges pointed out by the authors about palliative care at Primary Health Care, Santa Maria, Rio Grande do Sul, Brazil, 2020

\begin{tabular}{|c|c|c|c|}
\hline ARTICLE & CHALLENGES & ARTICLE & CHALLENGES \\
\hline 01 & $\begin{array}{l}\text { Centering PHC on the logic of care production, oriented to } \\
\text { users' problems, needs and quality of life, contemplating } \\
\text { not only curative procedures and actions, but human } \\
\text { relationships, bonding and welcoming. }\end{array}$ & 02 & $\begin{array}{l}\text { Provide patient-centered care rather than organizational logic, } \\
\text { as implemented by case managers. }\end{array}$ \\
\hline 03 & Develop innovative models for PC at PHC. & 04 & $\begin{array}{l}\text { Plan PC assistance at PHC, considering the discomforts and } \\
\text { difficulties in addressing issues that can cause suffering, } \\
\text { depression, or destroy hope. }\end{array}$ \\
\hline 05 & $\begin{array}{l}\text { Encourage the organization of an information flow } \\
\text { between secondary and primary care. }\end{array}$ & 06 & $\begin{array}{l}\text { Expand the scope of care and PC at PHC, including other } \\
\text { CNCDs and not just cancer. }\end{array}$ \\
\hline 07 & Train professionals to identify patients eligible for PC at PHC. & 08 & $\begin{array}{l}\text { Improve communication and the bond of trust between } \\
\text { patients and professionals. }\end{array}$ \\
\hline 09 & Also consider terminally ill families in care planning. & 10 & $\begin{array}{l}\text { Assess the expectations of patients and caregivers in relation to } \\
\text { care, aiming to improve the quality of life and avoid unnecessary } \\
\text { travel to emergency services in the final stage of the disease. }\end{array}$ \\
\hline 11 & $\begin{array}{l}\text { Create patient-centred care systems, promote patient } \\
\text { autonomy, improve quality of life, and lead to more } \\
\text { effective use of health care resources. }\end{array}$ & 12 & $\begin{array}{l}\text { End barriers to continuing education for professionals, } \\
\text { including workload and geographic isolation. }\end{array}$ \\
\hline 13 & $\begin{array}{l}\text { Improve the diagnosis and treatment of depression in PC } \\
\text { patients by PHC physicians through better communication } \\
\text { strategies in the doctor-patient relationship. }\end{array}$ & 14 & $\begin{array}{l}\text { Implement PC training and support to improve end-of-life } \\
\text { care capacity. }\end{array}$ \\
\hline 15 & $\begin{array}{l}\text { Ensure more timely, fair and equitable access to PC } \\
\text { in the community. }\end{array}$ & 16 & Need for continuous training of primary care physicians for PC. \\
\hline 17 & $\begin{array}{l}\text { Broaden the focus of PC, as most are very focused on } \\
\text { providing care in response to specific clinical processes, } \\
\text { such as malignant tumors. }\end{array}$ & 18 & $\begin{array}{l}\text { Implement PC for children due to lack of knowledge and } \\
\text { experience in this field. }\end{array}$ \\
\hline 19 & $\begin{array}{l}\text { Improve the organization of } \mathrm{PC} \text { at this level of care }(\mathrm{PHC}) \\
\text { and the work culture among health professionals. }\end{array}$ & 20 & $\begin{array}{l}\text { Establish individual goals for each patient according to their } \\
\text { framework, aiming at the implementation of PC. }\end{array}$ \\
\hline 21 & $\begin{array}{l}\text { The network's ineffectiveness in articulating the demands } \\
\text { with its consumption resources point to situations that bring } \\
\text { a reflection on the support of this network in relation to its } \\
\text { capacity to meet the demands of patients in finitude at home. }\end{array}$ & 22 & $\begin{array}{l}\text { Difficulties in medical training, limited availability of supplies } \\
\text { and human material can hinder a better provision of PC in } \\
\text { Brazilian PHC. }\end{array}$ \\
\hline
\end{tabular}

PHC - Primary Health Care; $P C$ - palliative care.

From this perspective, care is provided by a multidisciplinary team during the period of diagnosis, illness, finitude and grief. It is necessary to perceive individuals in all their completeness, including psychosocial and spiritual aspects in their care ${ }^{(1)}$.

The lack of psychological support for PHC professionals also appears as an experience that makes PC difficult. The most common causes of stress reported in the articles were related to the work environment, role conflict and issues with patients and their families. It is noteworthy that most nurses worked in home care environments ${ }^{(16)}$. Studies suggest that the care of patients with $\mathrm{PC}$ requires changes in relation to the practice of professionals, family members and caregivers, often causing wear and tear and decline in personal relationships ${ }^{(17)}$. 
It should be noted that there may be spiritual and psychological wear caused by patients and their caregivers (professionals and family members). Each patient will use a different way to express their suffering, and professionals must be open and explore what the patient brings to try to understand how they see their suffering; find out what lens patients use to see/verbalize how they are feeling. Thus, it is essential to approach a multidisciplinary team for a holistic assessment of the situation ${ }^{(31)}$.

Spiritual assessment is a complex and in-depth process for listening to patients and better understanding patients'spiritual resources and needs and then making a diagnosis and spiritual care plan. It is usually performed by a chaplain or a professional with specific training in spiritual care. It is important to emphasize that suffering can be alleviated, but it will not always be completely alleviated. Patients need someone who is, in fact, present to listen to their pain and anguish and be able to find answers. Therefore, it is so important that professionals are attentive and listen empathically, creating an environment of trust in which patients can express their anxieties ${ }^{(31)}$.

The studies also ${ }^{(19-20-21,23)}$ dealt with the insufficiency of professionals' management and training for PC and this theme was also evidenced in research ${ }^{(22,24)}$, pointing out that professionals' unpreparedness to deal with the demands and needs of chronic health conditions was present in countries such as Italy and Germany, which have a population aged longer than Brazil.

Given the current process of population aging and increased incidence of CNCDs, one of the studies highlighted that most patients in the world still die before having access to PC and that this care must be accessible and available in health units belonging to PHC. In addition to having the necessary resources and tools for the care of patients in PC, health professionals, policy makers, educators and national groups in general should target and facilitate the development of PC in the country ${ }^{(32)}$.

The results of other studies indicate that, in general, patients in PC still die in hospital environments, such as the Intensive Care Unit (ICU), despite the preference for the home environment. It also demonstrated as barriers for primary PC the lack of knowledge and skills in PHC; financial systems that do not allow PC refunds; problems in drug availability policies; lack of structure and professional or specialist support; lack of early identification of patients who need PC; limited understanding of management and population about this care ${ }^{(22)}$.

Within its scope, PHC has the potential to develop a set of interventions that favor the quality of life and continuity of PC inside and outside the home; potentially, it can favor and provide, to patients, care close to family and friends, in addition to reducing the risk of infections and suffering resulting from unnecessary hospitalizations ${ }^{(10-11,15,25,28-29)}$.

A Brazilian review, with the objective of understanding the role of $\mathrm{PHC}$ professionals in $\mathrm{PC}$, points out that the implementation of NASF-AB favors the monitoring of $\mathrm{PC}$ in $\mathrm{PHC}$, through the support of a multidisciplinary team. However, it is noted that $\mathrm{PHC} /$ FHS professionals run into difficulties such as the disarticulation with other points of the health care network, especially with the emergency services ${ }^{(33)}$, requiring an articulated management, with the establishment of flows and increased communication between health services ${ }^{(34)}$.
Another relevant aspect is the importance of amplifying PC supply to all diseases and not just for cancer patients. An international study carried out to investigate the referral of patients in PC to PHC concluded that they were generally cancer patients ${ }^{(28)}$. Initially, palliative practice was aimed at cancer patients, but gradually it was incorporated by other specialties involved in the care of patients with chronic-degenerative diseases. In its first edition, published in 1995, the "National Palliative Care (NHO) Medical Guidelines for Determining Prognosis in Selected Non-Cancer Diseases" determined the prognosis of non-cancer diseases and included them in PC programs. The first non-cancer diseases to be included were Congestive Heart Failure (CHF), Chronic Obstructive Pulmonary Disease (COPD), and Alzheimer's Disease ${ }^{(35)}$.

With regard to educational actions for $\mathrm{PC}$, the articles that make up this category were developed with the perspective of evaluating or reporting the impact of educational actions developed with professionals who are already inserted in the services. A study ${ }^{(21)}$ pointed out that addressing aspects related to death is still a great challenge for educators, especially in Western nations, considering that death is often associated with pain, suffering, punishment and not as an outcome stage of the life cycle. Added to this scenario is the fact that discussions about PC are still absent or superficial within academic training.

The same study ${ }^{(21)}$, which aimed to raise and analyze the theme of death and dying in academic nursing education, concluded that there is no preparation of nursing students on the subject. Moreover, professors feel insecure in working on issues related to death, because, in their training, they also had a deficient approach to the subject. Still, a specific education program for the subject is needed, considering a critical and reflective view of reality, which will provide the construction of pedagogical projects that contemplate not only a focus on cure, but on PC, aiming at a death with dignity.

Death, understood as a topic that is part of daily life of health services, integrates the different phases of the human life cycle, but it is still a topic treated in a reduced way, both in health professionals' training and in health services, compromising the integrality principle.

The study ${ }^{(14)}$ showed that the request by family members not to disclose the diagnosis to patients may coincide with professionals' choice, reinforcing their own difficulties with the subject. In some publications, the curative model still prevails, focused on the disease and the specificity of care. The training of professionals could favor health education aimed at patients and their families, especially in relation to the implementation of $\mathrm{PC}$ at $\mathrm{PHC}^{(8-9,12-13)}$. Furthermore, Permanent Health Education (PHE), considered learning at work, takes everyday life as an open space and permanent reviewer of professional practices as a place of subjectivity and discussions ${ }^{(36)}$. Thus, it is believed that institutionalized spaces that can analyze professional practices in an interdisciplinary way are essential for promoting PC comprehensiveness.

Regarding the challenges for $\mathrm{PC}$ at $\mathrm{PHC}$, it is noted that the largest portion of the challenges are related to the management, bonding and communication of $\mathrm{PC}$ at $\mathrm{PHC}$, mainly by the nursing staff. For $\mathrm{PC}$ to evolve at $\mathrm{PHC}$, it is necessary to plan the offer, identify and understand the needs, the available resources, 
practice sharing information through adequate communication and defining the commitments of the parties involved. This is done in relationships and collaborative practices between different professionals, families, and managers ${ }^{(13)}$.

For changes to occur within the scope of PC management, knowledge on the subject, the capacity for dialogue and problematization about the current conceptions within each health team is necessary. The construction of new pacts, with the approximation of concepts about comprehensive, humanized and quality care, in addition to equity and milestones that occurred strongly in the process of reform of the Brazilian health system, are essential for such changes to occur ${ }^{(36)}$. PC must be performed by a multidisciplinary team, with the integration of health networks to provide continuity of care and always include individuals and their families in care, providing opportunities for effective communication in the team's relationship with patients/family ${ }^{(37)}$.

Although working in PC is a team, nursing professionals are identified as key components to the success of PC, since they are the most responsible for monitoring patients' clinical situation, i.e., they are the ones who assess pain, the results of therapeutic treatments and the presence of side effects, thus collecting information relevant to the reorganization of the analgesic process and other non- pharmacological when the need is identified. Another function performed by the area is communication, considered in the $\mathrm{PC}$ process as one of the most relevant pillars. Its practice is essential in all stages of the disease, contributing to clarification of doubts, in addition to allowing patients and/or family members to express their anxieties, anxieties and fear ${ }^{(38)}$.

In summary, nursing is responsible for carrying out different activities that, in partnership with other professionals that make up the multidisciplinary team of PC, contribute to the promotion of the well-being of patients with any pathology, with no therapeutic possibility of cure, in addition to expanded family care.

\section{Study limitations}

The possible limitations of this study refer to the sample, as only articles available online and free of charge were included, which may have led to the non-inclusion of some studies related to the theme and the low level of evidence of studies used according to the adopted classification.

\section{Contributions to nursing}

Based on the results found, it is suggested to managers a redirection in the conduct of practice that is anchored in selfknowledge and contemplates the strengthening of nurses as care manager sand immediate leaders of the care team. PHC managers, through the results of the survey, can strengthen the training practice of professionals involved in the care of PC patients through professional training and community awareness about the role and importance of PC.

It is also suggested that PC be included in undergraduate and graduate nursing curricula.

\section{FINAL CONSIDERATIONS}

The evidence found relating $\mathrm{PC}$ in $\mathrm{PHC}$ points to the possibility of this care, since the health teams work closely with the family and their home, with the possibility of greater bonding and resoluteness. However, the need to expand this theme is still perceived with the pedagogical projects of courses in the health area, especially in the context of undergraduate nursing courses, allowing students to problematize and live experiences they will have to face in professional practice, in addition to the implementation of permanent education and health education actions with professionals working in health care networks.

SUS, when it was structured, did not develop in its scope the incorporation of PC, but, currently, it is known that it is possible to be restructured in order to incorporate them. This situation is corroborated, in 2018, with the guidelines for PC organization, in the light of integrated continuous care, within the scope of SUS. However, there are still challenges in the management and structure of the system, especially the lack of training and specific educational actions to care for patients and their families.

It is essential to master communication strategies, such as sensitive listening and understandable and objective speech, by all health professionals who make up the multidisciplinary support that has contact with patients in PC and their families. The health sector is changing, and, constantly, professionals responsible for care need to reinvent themselves in order to overcome challenges and exercise their professional role in society with zeal and ethics.

Currently, PC is experienced by PHC professionals and it is essential to care for patients and their families, based on technical and scientific knowledge. It is necessary for nurses and managers to know that they recognize patients who need $\mathrm{PC}$, but also offer quality care aimed at the well-being of patients and their families. PHC teams in Brazil must act on two fronts. In one of them, the training of health professionals through meetings to discuss the theme, with specific information about PC for different specialties. The second front is to develop actions to sensitize the community about the role and importance of PC, emphasizing its benefits when introduced early through open meetings, specific meetings for caregivers and presentations of the theme to municipal councils.

\section{ACKNOWLEDGMENT}

Special thanks to all members of the Study and Research Group in Nursing and Health (UFSM).

\section{REFERENCES}

1. World Health Organization (WHO). WHO definition of palliative care[Internet]. Genebra; 2002 [cited 2020 Mar 10]. Available from: http:// www.who.int/cancer/palliative/definition/en/ 
2. Ho A, Jameson K, Pavlish C. An exploratory study of interprofessional collaboration in end-of-life decision-making beyond palliative care settings. J Interprof Care. 2016;30(6):795-803. https://doi.org/10.1080/13561820.2016.1203765

3. Ministério da Saúde (BR). Resolução n 41, de 31 de outubro de 2018. Dispõe sobre as diretrizes para a organização dos cuidados paliativos, à luz dos cuidados continuados integrados, no âmbito Sistema Único de Saúde (SUS) [Internet]. Brasília, 2018[cited 2020 Mar 10]. Available from: https://conselho.saude.gov.br/resolucoes/2018/Reso573.pdf

4. Ministério da Saúde (BR). Portaria no 648/GM de 28 de março de 2006. Aprova a Política Nacional de Atenção Básica, estabelecendo a revisão de diretrizes e normas para a organização da Atenção Básica para o Programa Saúde da Família (PSF) e o Programa Agentes Comunitários de Saúde (PACS) [Internet]. Brasília: Ministério da Saúde; 2006[cited 2020 Mar 10]. Available from: http://bvsms.saude.gov.br/ bvs/publicacoes/prtGM648_20060328.pdf

5. Liberati A, Altman DG, Tetzlaff J, Mulrow C, Gøtzsche PC, loannidis JP, et al. The PRISMA statement for reporting systematic reviews and meta-analyses of studies that evaluate healthcare interventions: explanation and elaboration. BMJ. 2009;339:b2700. https://doi. org/10.1136/bmj.b2700

6. Mendes KDS, Silveira RCCP, Galvão CM. Revisão integrativa: método de pesquisa para a incorporação de evidências na saúde e na enfermagem. Texto Contexto Enferm. 2008;17(4):758-64. https://doi.org/10.1590/S0104-07072008000400018

7. Bardin L. Análise de conteúdo. São Paulo: Edições 70; 279 p. 2011.

8. Baliza MF, Bousso RS, Spineli VMCD, Silva L, Poles K. Palliative care in the home: perceptions of nurses in the Family Health Strategy. Acta Paul Enferm. 2012;25(2):13-8. https://doi.org/10.1590/S0103-21002012000900003

9. Van der Plas AG, Francke AL, Vissers KC, Jansen WJ, Deliens L, Onwuteaka-Philipsen BD. Case management in primary palliative care is associated more strongly with organisational than with patient characteristics: results from a cross-sectional prospective study. BMC Palliat Care. 2015;14(31). https://doi.org/10.1186/s12904-015-0029-8

10. Corrêa SR, Mazuko C, Mitchell G, Pastrana T, Lima L, Murray S. Identificando pacientes para cuidados paliativos na atenção primária no Brasil: experiência do Projeto Estar ao Seu Lado. Rev Bras Med Fam Comunidade [Internet]. 2017 [cited 2021 Apr 28];12(39):1-8. Available from: https://www.rbmfc.org.br/rbmfc/article/view/1507

11. Ghosh A, Dzeng E, Cheng MJ. Interaction of palliative care and primary care. Clin Geriatr Med. 2015;31(2):207-18. https://doi.org/10.1016/j. cger.2015.01.001

12. Offen J. The role of UK district nurses in providing care for adult patients with a terminal diagnosis: a meta-ethnography. Int J Palliat Nurs. 2015;21(3):134-41. https://doi.org/10.12968/ijpn.2015.21.3.134

13. Van der Plas AG, Onwuteaka-Philipsen BD, Francke AL, Jansen WJ, Vissers KC, Deliens L. Palliative care case managers in primary care: a descriptive study of referrals in relation to treatment aims. J Palliat Med. 2015;18(4):324-31. https://doi.org/10.1089/jpm.2014.0269

14. Murray SA, Firth A, Schneider N, Van den Eynden B, Gomez-Batiste X, Brogaard T, et al. Promoting palliative care in the community: production of the primary palliative care toolkit by the European Association of Palliative Care Taskforce in primary palliative care. Palliat Med. 2015;29(2):101-11. https://doi.org/10.1177/0269216314545006

15. Faull C, Windridge K, Ockleford E, Hudson M. Anticipatory prescribing in terminal care at home: what challenges do community health professionals encounter? BMJ Support Palliat Care. 2013;3(1):91-7. https://doi.org/10.1136/bmjspcare-2012-000193

16. Álvarez-Cordovés MM, Mirpuri-Mirpuri PG, Gonzalez-Losada J, Chávez-Díaz B. Cuidados paliativos en atención primaria: a propósito de un caso. Semergen. 2013;39(7):396-9. https://doi.org/10.1016/j.semerg.2012.05.009

17. Pelayo-Alvarez M, Perez-Hoyos S, Agra-Varela Y. Clinical effectiveness of online training in palliative care of primary care physicians. J Palliat Med. 2013;16(10):1188-96. https://doi.org/10.1089/jpm.2013.0005

18. Beyea A, Fischer J, Schenck A, Hanson LC. Integrating palliative care information and hospice referral in medicaid primary care. J Palliat Med. 2013;16(4):376-82. https://doi.org/10.1089/jpm.2012.0483

19. Johansen ML, Ervik B. Teamwork in primary palliative care: general practitioners' and specialised oncology nurses' complementary competencies. BMC Health Serv Res. 2018;18(1):159. https://doi.org/10.1186/s12913-018-2955-7

20. Warmenhoven F, Van Rijswijk E, Van Hoogstraten E, Van Spaendonck K, Lucassen P, Prins J, et al. How family physicians address diagnosis and management of depression in palliative care patients. Ann Fam Med. 2012;10(4):330-6. https://doi.org/10.1370/afm.1373

21. Murray SA, Osman H. Primary palliative care: the potential of primary care physicians as providers of palliative care in the community in the Eastern Mediterranean region. East Mediterr Health J. 2012;18(2):178-83. Available from: https://apps.who.int/iris/handle/10665/118464

22. Cameron BL, Salas AS, Moissac D. Participatory knowledge exchange to support palliative care in Chile: lessons learned through global health research. Can J Nurs Res. 2011;43(3):16-37. Available from: https://pubmed.ncbi.nlm.nih.gov/21977724/

23. Nnadi DC, Singh S. Knowledge of palliative care among medical interns in a tertiary health institution in Northwestern Nigeria. Indian J Palliat Care [Internet]. 2016 [cited 2021 Apr 29];22:343-7. Available from: https://www.jpalliativecare.com/text.asp?2016/22/3/343/185080

24. Reigada C, Arantzamendi, Centeno C. Palliative care in its own discourse: a focused ethnography of professional messaging in palliative care. BMC Palliat Care. 2020;88(19). https://doi.org/10.1186/s12904-020-00582-5

25. Winger A, Kvarme LG, Løyland B, Kristiansen C, Helseth S, Ravn IH. Family experiences with palliative care for children at home: a systematic literature review. BMC Palliat Care. 2020;19(1):165. https://doi.org/10.1186/s12904-020-00672-4 
26. Berggren E, Ödlund Olin A, Orrevall Y, Strang P, Johansson SE, Törnkvist L. Early palliative home care: evaluation of an interprofessional educational intervention for district nurses and general practitioners about nutritional care. SAGE Open Med. 2017;5:2050312117726465. https://doi.org/10.1177/2050312117726465

27. Schneider N, Lueckmann SL, Kuehne F, Klindtworth K, Behmann M. Developing targets for public health initiatives to improve palliative care. BMC Public Health. 2010;10:222. https://doi.org/10.1186/s12904-016-0149-9

28. Marques FP, Bulgarelli AF. Os sentidos da atenção domiciliar no cuidado ao idoso na finitude: a perspectiva humana do profissional do SUS. Ciênc Saúde Colet. 2020;25(6):2063-72. https://doi.org/10.1590/1413-81232020256.21782018

29. Wassmansdorf Mattos C, D’Agostini Derech R. Cuidados paliativos providos por médicos de família e comunidade na atenção primária à saúde brasileira: um survey nacional. Rev Bras Med Fam Comun [Internet]. 2020[cited 2021 Apr 29];15(42):2094. Available from: https:// rbmfc.org.br/rbmfc/article/view/2094

30. Melnyk BM, Fineout-Overholt E. Making the case for evidence-based practice. In: Melnyk BM, Fineout-Overholt E. Evidence-based practice in nursing \& healthcare: a guide to best practice. Philadelphia: Lippincot Williams \& Wilkins; 2005. p.3-24.

31. Silva CP, Pirol SM. Organização do serviço para o cuidado paliativo: revisão bibliográfica. Rev Univ Vale Rio Verde. 2018;16(2):1-11. http:// dx.doi.org/10.23973/ras.70.85

32. Paz CRP, Pessalacia JDR, Zoboli ELCP, Souza HL, Granja GF, Schveitzer MC. New demands for primary health care in Brazil: palliative care. Invest Educ Enferm. 2016;34(1):46-57. https://doi.org/10.17533/udea.iee.v34n1a06

33. Afshar K, Geiger K, Müller-Mundt, G. Generalist palliative care for non-cancer patients. Schmerz 2016. https://doi.org/10.1007/ s00482-016-0135-4

34. Mounsey L, Ferres M, Eastman P. Palliative care for the patient without cancer. Aust J Gen Pract. 2018;47(11):765-9. https://doi.org/10.31128/ AJGP-07-18-4625

35. Azevedo C, Rates CMP, Pessalacia JDR, Mata LRF. Perspectivas para os cuidados paliativos na atenção primária à saúde: estudo descritivo. $O$ Braz J Nurs. 2016;15(4):683-93. https://doi.org/10.17665/1676-4285.20165370

36. Azevedo C, Pessalacia JDR, Mata LRF, Zoboli ELCP, Pereira MG. Interface between social support, quality of life and depression in users eligible for palliative care. Rev Esc Enferm USP. 2017;28(51):e03245. https://doi.org/10.1590/S1980-220X2016038003245

37. Meneguin S, Ribeiro R, Ferreira MLSM. Conforto de cuidadores formais e informais de pacientes em cuidados paliativos na atenção primária à saúde. Rev Rene. 2016;17(6):797-803. https://doi.org/10.15253/2175-6783.2016000600010

38. Marchi JA, Paula CC, Girardon-Perlini NMO, Sales CA. The meaning of being a caregiver of a dependent relative suffering from cancer: palliative contributions. Texto Contexto Enferm. 2016;25(1):e0760014. Available from: https://doi.org/10.1590/0104-07072016007600014 